\title{
Refuge
}

Canada's Journal on Refugees

revue canadienne sur les réfugiés

\section{Afer the Flight: The Dynamics of Refugee Settlement and Integration, by Morgan Poteet and Shiva Nourpanah (Eds.)}

\section{Julia Morris}

Volume 34, Number 2, 2018

URI: https://id.erudit.org/iderudit/1055590ar

DOI: https://doi.org/10.7202/1055590ar

See table of contents

Publisher(s)

Centre for Refugee Studies, York University

ISSN

0229-5113 (print)

1920-7336 (digital)

Explore this journal

Cite this review

Morris, J. (2018). Review of [Afer the Flight: The Dynamics of Refugee

Settlement and Integration, by Morgan Poteet and Shiva Nourpanah (Eds.)].

Refuge, 34(2), 157-158. https://doi.org/10.7202/1055590ar

Copyright (c) Refuge: Canada’s Journal on Refugees, 2018

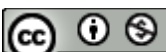

This document is protected by copyright law. Use of the services of Erudit (including reproduction) is subject to its terms and conditions, which can be viewed online.

https://apropos.erudit.org/en/users/policy-on-use/ 
of the themes characteristic of "life in Kakuma" might have been chosen by her interlocutors on the basis of that role.

I would have liked to see more of the youths' voices and ethnographic detail in earlier chapters to further humanize the argument she was making. While she provides very rich histories of the migration process and descriptions of institutional expectations, I wanted to hear about which artists local DJs were using to mix with Somali musicians on bootlegged and dubbed CDs and tracks. I wanted to hear a little about the latest wedding video that was circulating and that groups watched to admire, tease, envy, and criticize. When hearing about life in Kakuma I missed some of the everyday ways of being-not just the everyday violence. I wanted to read about the conversations these young people had with their families when they brought home or staged the photographs. I wanted to hear about how they went through the market to buy Eid el Fatr gifts and ingredients for the dinner.

I think Children of the Camp will be an important read for anyone interested in youth in protracted refugee status.

Anna L. Jacobsen is a lecturer in the Department of Anthropology, Washington University in St. Louis. The author may be reached at aljacobs@wustl.edu.

\title{
After the Flight: The Dynamics of Refugee Settlement and Integration
}

\author{
$\sim$ \\ Edited by Morgan Poteet and Shiva Nourpanah \\ Newcastle upon Tyne: Cambridge Scholars Publishing, 2018, 278 pp.
}

I ntegrating into a new locality can be very challenging for refugees. After the Flight: The Dynamics of Refugee Settlement and Integration focuses on some of the extreme barriers refugees face to their civic participation. Globally, a punitive political climate sees asylum seekers and refugees demonized as terrorists or welfare scroungers; alternatively, many are also belittled as vulnerable. Meanwhile, cuts to settlement services have been felt across the sector, characterized by a culture of mistrust and misunderstanding.

After the Flight is an edited volume that, after a brief introduction by the editors, is divided into eleven chapters-each depicting case studies of refugee integration in the Global North. The book develops its focus with attention to detailed empirical research and an emphasis on human agency. The chapters draw from extensive interviews and time spent with key individuals across the resettlement landscape from refugees to NGOs, academics, and immigration officials. Throughout, the attention to representing refugees as resourceful agents, who at times construct their own forms of integration, aims to counter patronizing depictions.

The book is divided into two main sections focused on the socio-cultural integration in host contexts and specific approaches to integration. In the first section, chapters trace the social and cultural landscape that refugees integrate to and from. Baker et al. emphasize the importance of acquiring citizenship for identity formation. The experience of Bhutanese Lhotshampa refugees moving from Nepalese refugee camps to small-town life in Newfoundland is fractured, with little sense of political and civic stability. Refugees develop what the authors refer to as a "cultural toolkit," drawing from past and present experiences to build an identity, which encompasses a sense of self-assurance. Malischewski, on the other hand, flips the focus to the vestiges of turbulence in the host country, in particular the many layers of segregation encountered by refugees resettling in Northern Ireland. Northern Ireland has seen a dramatic rise in asylum claims in recent years, but sectarian and local/foreigner divisions complicate integration. This chapter opens up interesting debates around integration when the norm is not to integrate but to live in sectarian divided neighbourhoods.

Following the focus on identity formation, the contributions move to develop questions of structure and agency. Nourpanah emphasizes the importance of seeing refugees as resourceful agents in her study of the integration of Afghan refugees in Halifax. Here refugees are subject to negative public stereotypes as fundamentalist Muslims or victims suffering loss and trauma. Nourpanah considers how refugees respond to the matrix that they find themselves fitting into, giving a fuller picture of people as creative and skilled workers. MacLaren et al. also provide an important critique of government policy, underlining the crucial role of networking among Karen refugees from Burma resettled in Australia. Refugees also encounter a toxic political discourse in Australia. The authors make specific recommendations for settlement agencies, including understanding people's cultural particularities and the importance of forging a culture of welcome. Finally, Ward turns the mirror on academics, arguing that they help shape the problematization of refugees. She raises important concerns, pointing out that academics tend to emphasize refugee vulnerability or focus research on 
certain refugee groups as "more vulnerable" or important than another. However, funding prerogatives hinder more critical, alternative refugee research.

Throughout, the chapters take care to balance theoretical frames with ethnographic description and qualitative research. In the second section, the chapters move into more detail on integration practices themselves. In particular, Mantei takes a feminist perspective of fabric arts as gendered text among Karen women moving from Burma to Thai refugees camps to resettlement in Saskatchewan, Canada. Weaving becomes a way for women to connect to the past, even as the weaving shifts in meaning and utility for women. Holt and Laitsch's chapter examines settlement practices in schools for refugee students adjusting to the new education system. They look at the experience of settlement workers, providing specific areas for improvement as well as highlighting the role that schools play. Sienkiewicz and Nichols keep the focus on institutional models, charting the evolution of settlement houses in the United States. Drawing on ethnographic research at a resettlement complex in North Carolina, they argue that increased communication and targeted recruitment are required to bolster integration into communities across ethno-national and racial divides.

Key strengths of this book are the authors' suggestions for pragmatic approaches of reform. Hynie et al. develop a holistic model of integration drawn from a refugee resettlement study in six Ontario cities. They stress the importance of considering subjective variables, such as feelings of belonging and of being at home, as part of a larger holistic integration model. Bose, on the other hand, looks at the successes and challenges of a mutual aid association staffed primarily by refugees in Vermont. He makes recommendations to improve the resettlement experience, centring his methodology on participatory action research. Poteet provides an uplifting conclusion to the book, considering a more expansive notion of integration among Central American male youth in Toronto of refugee origin. Supports are most effective when young people are encouraged to take action themselves and be involved in decision-making. This chapter makes clear-as is the case throughout the book-the challenges faced by the current restrictions of refugee policy, in particular the lack of support for community agencies.

This book is an effort to comparatively study the resettlement landscape in English-speaking countries in the Global North. What emerges is a nuanced portrait of the challenges of integration for refugees and concrete suggestions for developing better models of service delivery. Although helpful to focus on countries that have similar integration systems, omitting countries outside of the Global North does inscribe developmentalist North/South divides. In this regard, future research might consider the many ways in which people are creating local response structures, including more informal forms of hospitality in major refugee hosting contexts outside the Global North. At the same time, future researchers may also wish to reflect on forms of resettlement available not just for government-assisted refugees. Ontario's new Conservative government recently announced that no support will be provided for the costs associated with asylum seekers crossing from the United States. In this context, it is important to understand the integration landscape for arrivals outside of institutional resettlement responses. Certainly this book has exciting implications for future research avenues. Its rich ethnographic detail and theoretically attuned exploration of the dynamics of refugee settlement and integration will make it invaluable to scholars, practitioners, and policy-makers interested in forced migration and resettlement across the social sciences and humanities.

Julia Morris is a post-doctoral fellow in the Zolberg Institute on Migration and Mobility at the New School. The author may be reached at julia.morris@newschool.edu.

\section{Asylum after Empire: Colonial Legacies in the Politics of Asylum Seeking

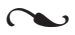 \\ Lucy Mayblin \\ Lanham, MD: Rowman and Littlefield International, 2017, 200 pp.}

$\mathrm{L}$ ucy Mayblin's book offers a sociological history of asylum policies in Great Britain through a post-colonial and a de-colonial approach that defines the refugee as "the embodiment of the darker side of modernity and of the global fallout of colonialism" (3). The first of eight chapters provide an excursus of Great Britain's toughening laws against migration during the 1990s, which stemmed from the government's approach to the 1951 Geneva Refugee Convention and the related 1967 Protocols. The author builds on Chimni's " "myth of difference," according to which there were no non-EU migrants moving toward Great Britain after the massive displacement of the Second World War. Drawing 